\title{
THE RULE OF LAW APPROACH TO REGULATING ELECTRICITY SUPPLY IN NIGERIA
}

\author{
Sam Amadi*
}

\begin{abstract}
With the transfer of government shares in 17 electricity generation and distribution companies in November 2013, Nigeria crossed the Rubicon in the privatization process. This process began in earnest in 2003 with the liberalization of the telecom sector as part of a strategic reform to improve efficiency in these utility sectors. So far, privatization has not improved the quality of service in these sectors. The problem has been traced to the failure of regulation. The major problem is that the regulatory regime had not matured before privatization. This immaturity manifests mostly in the failure to protect consumer interests. This article reviews regulatory deficits post-privatization. It assesses potential conflict between principles of market orthodoxy and those of constitutional governance and argues for a rule-of-law approach to regulation post-privatization that is focused on blending of promotion of market efficiency and protection of fundamental rights.
\end{abstract}

Keywords: Liberalization, Privatization, Regulation, Market Efficiency, Rule of Law

DOI: https://dx.doi.org/10.4314/jsdlp.v8i2.2

\section{INTRODUCTION}

In November 2013, Nigeria achieved a commendable feat of conducting what is generally believed to be one of the largest single privatization exercises in the world. ${ }^{1}$ The country handed over ownership of six

* LL.B (Calabar), LL.M, MPA, SJD (Harvard), Senior Lecturer, Faculty of Law, Baze University, Abuja, Nigeria; formerly Chairman and Chief Executive, Nigerian Electricity Regulatory Commission (NERC) 2010-2015. Correspondence e-mail: samadi29@yahoo.com

1 The need for privatizing the electricity sector was originally articulated in the National Electric Power Policy (NEPP) 2001 and later incorporated in the Electric Power Sector Reform (EPSR) Act 2005. 
electricity generation companies and 11 electricity distribution companies to private firms. ${ }^{2}$ This followed on the heels of contracting the country's transmission service provider to private management contractors. ${ }^{3}$ The two exercises almost completed the full privatization of the entire electricity industry in Nigeria. ${ }^{4}$ The privatization of the electricity industry is part of a larger economic reform programme of the government, which started in 1999 with President Obasanjo. The Obasanjo administration articulated the National Electric Power Policy (NEPP) in 2000 and followed it up during his second tenure with the enactment of the Electric Power Sector Reform (EPSR) Act, 2006. The policy thrusts of the NEPP include liberalization of the electricity industry by allowing licensing of independent power producers (IPPs), unbundling of the vertically integrated utility service monopoly provider - the National Electric Power Authority (NEPA), corporatization and commercialization of the electricity value-chains and independent regulation of the entire sector. As part of the independent regulation of the entire electricity industry, the policy further restricts the Ministry of Power (or any other nomenclature it may bear) to policy-making on electricity supply. ${ }^{5}$

The power sector reform follows after a largely successful reform of the telecommunications sector in the late 1990s and early 2000. That reform resulted in the licensing of private telecom firms to provide mobile telephony services and later data services to Nigerian homes and businesses. The later effort to privatize the publicly owned Nigerian Telecommunication Limited (NITEL) was a huge failure. ${ }^{6}$ But the

2 The six generating companies include two hydro stations that were sold as a concession to private firms. Those are Kanji Hydro Plant Station and Shiroro Hydro Plant Station.

3 The country's transmission service provider - the Transmission Company of Nigeria (TCN) was contracted in 2012 to the Manitoba Hydro of Canada for managers preparatory to possible privatization. See Editorial,"Canadian firm wins USD24m Nigerian power deal"Biztech Africa (5 April 2012) < http:// www.biztechafrica.com/article/canadian-firm-wins-usd24m-nigerian-powerdeal/2474/> accessed on Tuesday, 29 August 2017

4 The only exceptions are the 10 Nigerian Integrated Power Plants (NIPPs), which are awaiting completion of the privatization and a few power plants owned by some major oil companies in Nigeria.

5 See, generally, National Council on Privatization, National Electric Power Policy (Federal Republic of Nigeria, 2001) for the policy thrusts of the electricity sector reform in Nigeria.

6 See Ngozi Okonjo-Iweala, Reforming the Unreformable: Lessons from Nigeria (MIT Press, 2012) 43-45 for a brief discussion of the liberalization of the telecom sector and the privatization of NITEL and its mobile arm, MTEL. 
ultimate outcome of the reform is that today Nigerians are enjoying mobile telephony services almost everywhere in the country. Nigeria is today adjudged as the country with one of the fastest growing mobile services and the most penetrated in the world. ${ }^{7}$ Although the quality of mobile services Nigerians receive is very poor judging by the global quality of service standards, many Nigerians continue to point to the liberalization of the telecom sector as the few successes of the government's neoliberal economic reform programme. The success consists in the fact that Nigerians moved from almost zero access to telephony services to a situation where almost every household can boast of ownership of a mobile phone and access to mobile phone services. This success is attributed to the policy of liberalization and commercialization of the telecom sector which was part of a comprehensive infrastructure development plan of the Federal Government starting from towards the end of military rule in the late 1990s.

Privatization began with the military administration of former Head of State, General Ibrahim Babangida, as part of the conditionality for the Structural Adjustment Programme (SAP) imposed on Nigeria and similar fiscally troubled economies in sub-Saharan Africa in the late 1980s. ${ }^{8}$ Babangida began the reform with the Privatization and Commercialization Act of 1988 as a regulatory framework. ${ }^{9}$ In 1993, the government established the Technical Committee for Privatization and Commercialization (TCPC) to coordinate the privatization and commercialization activities of the military government. Later on, with the return to civil rule in 1999, the government enacted the Public Enterprises (Privatization and Commercialization) Act, which created the National Council on Privatization (NCP) as the highest policymaking organ of the government on privatization issues. ${ }^{10}$

The Act also created the Bureau for Public Enterprises (BPE) to replace the TCPC as the technical operator and task manager of the public enterprises reform policy of the government. ${ }^{11}$ As part of telecom

7 Ibid.

8 See Dickson Eyoh and Richard Sandbrook, "Pragmatic Neo-Liberalism and Just Development in Africa" in Atul Kohli, Chung-in Moon, and Georg Sorensen (eds), States, Market, and Just Growth (United Nation University, 2003), 227 for general discussion of economic policy in Africa.

9 Privatization and Commercialization Act 1988, s. 3.

10 Public Enterprises (Privatization and Commercialization) Act 1999, s. 9.

11 ibid s. 12. 
reform programme, the government enacted the Nigerian Communication Commission Act that created the Nigerian Communication Commission (NCC) as the technical and economic regulator of the telecom sector. NCC established a licensing regime that resulted in the licensing of independent telecom operators like the MTN, ECONET (now Airtel), and MTEL. ${ }^{12}$ As part of the reform policy, the BPE failed in more than three attempts to sell NITEL and its mobile arm - MTEL - to core investors until 2015 when MTEL was successfully sold to a local consortium. ${ }^{13}$

It was the relative success in the reform of the telecom sector that inspired the reform of the electricity sector. The NCP issued the NEPP to offer policy direction for the electricity sector reform. NEPP's policy priority is "to create efficient market structures, within clear regulatory frameworks, that encourage more competitive markets for electricity generation and sales (marketing), which at the same time, are able to attract private investors and ensure [an] economically sound development of the system". ${ }^{14}$ The law followed it up with a structure for the emergence of a competitive electricity market. ${ }^{15}$

First, it stipulates liberalization through licensing, unbundling of the public monopoly utility, corporatization and commercialization of the successor companies and, later in the transitional stage, privatization of the now-corporatized successor companies. The law created a holding company, the Power Holding Company of Nigeria (PHCN), which is further separated into 18 different companies (6 electricity generation companies, 11 distribution companies and a national transmission company).

Towards the end of the transitional period, the law recommends that the six generating companies and the 11 distribution companies be sold to core investors as a way of guaranteeing a competitive electricity market in Nigeria. The implementation of the electric reform policy was stalled between 2007 and 2009 under President Yar'Adua. In 2010 President Jonathan restarted implementation of the reform with a Presidential Roadmap for Power Sector Reform. That strategy document articulated the urgency to privatize the sector by focusing

12 The first licenses were issued in 2001. Later in 2003, a wholly Nigerian telecom company, Glo, was licensed to provide mobile telephony services.

13 See Ngozi Okonjo-Iweala (n 6).

14 Paragraph 2.0 of NEPP, page 2.

15 Electric Power Sector Reform Act No. 62005. 
on removing "obstacles to private sector investment" and "clarifying the government's strategy on the divestiture of the PHCN successor companies". ${ }^{16}$ Thenceforth, the government made haste to privatize the entire electricity sector - handling all the public assets to private operators who have no proven track record in electricity generation and distribution in Nigeria.

It ought to be noted that just as the first licenses for telecom operators were issued shortly after the establishment of the NCC and even before erecting a formidable framework for regulating the fastapproaching privately managed telecom market, the privatization of the electricity industry occurred before the regulatory regime for the new electricity market has been fully established. The case of the Nigerian Electricity Regulatory Commission - the regulator of the electricity industry - is even more pathetic. The commission began work in 2006 when the first set of commissioners was appointed. In 2009 those commissioners were forcefully removed from office, and the Commission had no leader until December 2010 when President Goodluck Jonathan appointed fresh commissioners to steer the privatization of the sector. Clearly, by 2013 when private firms took over the sector, the regulatory landscape of the electricity had not been fully established.

The absence of maturation time in the regulatory landscape before full-scale privatization has severe implications for the sector's postprivatization performance. Today, Nigerians continue to complain bitterly about rampant service failures in both the telecom and electricity sectors. Service failure in telecom is mitigated because of the general euphoria with the availability of access to telecom services. In 1999, NITEL could boast of only 45,000 landlines, but, by 2010, thanks to the decade-long revolution in the mobile network, the number had increased to 85 million. ${ }^{17}$ This dramatic increase does not deny the universal poor quality of service in the country's telecom sector.

Drop calls are so rampant in the country, and many Nigerians own multiple mobile telephones in order to access service because of incessant service failures. The cost of making calls in Nigeria is far higher than in other places, and customer complaints are rife with

16 The Presidency, Federal Republic of Nigeria, Roadmap for Power Sector Reform (A Customer-Driven Sector-Wide Plan to Achieve Stable Power Supply) paragraph 1.0.

17 Ngozi Okonjo-Iweala (n 6), 43. 
many accusing the NCC of regulatory capture, collusion and incapacity. The electricity sector is worse because of the structural difficulties of the electricity network. All indicators of service improvement - hours of electricity supply, frequency and duration of outages, metering of customers, billing accuracy and prompt response to complaints - are all very parlous. Operators and regulators are agreed that the electricity reform in Nigeria has failed to deliver on its promises. There are now serious calls by some stakeholders to review and revise the privatization of the sector. ${ }^{18}$

Part of the cause of service failure is corruption and the deliberate manipulation of the market. Overpricing of services is one of the complaints by consumers of both telecom and electricity. In the telecom sector, the price is not strictly regulated, and competition amongst the providers is expected to keep prices within the range of affordability. This is dependent on the theory of a perfect market where information is readily available, and cost of migration to cheaper service providers is negligible. In reality, there could be collusion between providers while customers remain unable to switch suppliers of telecom services. In the electricity industry, many consumers are complaining of being exploited by the distribution companies who do not provide reliable and adequate electricity but issue exaggerated estimated bills. More importantly, there is no choice of service provider as the Nigerian electricity distribution is a private monopoly were customers are captives of the distribution company with an exclusive franchise in a defined territory. ${ }^{19}$

This article argues that the speed with which privatization was completed without ensuring strong normative and legal frameworks for a robust regulatory regime could mean that the notional gains of privatization may become a chimera and may not even endure where those gains are real. ${ }^{20}$ The regulatory landscape in Nigeria is even weaker

18 "Power sector privatization has failed-Saraki" The Punch (10 January 2017) <http://punchng.com/power-sector-privatisation-failed-saraki/> accessed 3 September 2017; Owede Agbajileke, "Privatization in power sector has failed Senate" Businessday (24 May 2017) < http://www.businessdayonline.com/ privatisation-power-sector-failed-senate/>accessed 3 September 2017.

19 Under the transitional arrangement in the power sector reform the distribution segment of the electricity market is a monopoly where a licensed firm has exclusive mandate to provide both distribution and resale to every customer on that network. There is no other of electricity except the exclusive holder of the distribution license. See Electric Power Sector Reform (EPSR) Act, s.67.

20 Stiglitz argues that privatization as part of the Washington Consensus proceeded 
because of the underdevelopment of the rule of law framework for regulating a private sector utility market. Efficient and competitive utility markets are built around certain disciplines that can be easily described as the rule of law disciplines. This includes a strong code of corporate conducts, pricing regimes that are transparent and accountable, strong competition and antitrust regulations, technical and economic regulation based on a substantive conception of justice. Unfortunately, these do not exist in our regulatory landscape making consumer protection and quick improvement in the quality of service extremely difficult. ${ }^{21}$

This article is divided into six sections. After this introduction, section 2 examines the regulatory landscape in Nigeria, its theoretical foundations and the historical context of privatization. It zeros in on Nigeria's preference for sector-specific, rather than global, regulator. Section 3 explores the general theoretical perspective of regulation, especially the economic theory assumptions of a perfect market and cast this in the context of a rule of law perspectives, especially in the context of Nigerian constitutionalism. Section 4takes further the constitutional law critique by arguing that beyond the ideal of promoting competition, separation of power as a constitutional theory secures political accountability in regulatory work. Section 5 focuses the conceptual evaluation of the challenges of regulation on the imperative of promoting human rights, especially in the regulator's exercise of quasi-judicial and quasi-legislative functions. Section 6 concludes the article by restating that the constitution imposes a rule of law challenge on utility regulator in Nigeria.

\section{REGULATORY LANDSCAPE IN NIGERIAN PRIVATIZATION}

Regulation intersects the worlds of economic theory and constitutional rights. ${ }^{22}$ Regulation can be conceived from two perspectives. The first

on the fatal assumption that change of ownership without adequate provision of regulatory institutions would result in efficiency and economic growth. This ideological mindset resulted in gross failure in the transitional and developing economies. See Joseph Stiglitz, Globalization and its Discontent (Penguin Books 2002), 54-58.

21 Both the electricity regulator and the telecom regulator all have statutory obligations to protect consumer welfare. See Nigerian Communication Commission Act 2003, s.3(1) and Electric Power Sector Reform Act 2005, s. 32.

22 See Cass R. Sunstein, After the Rights Revolution: Reconceiving the Regulatory State (Harvard University Press 1990) for a robust discussion of how economic theory and law intersect in market regulation. 
is the perspectives of simulating the ideal conditions necessary for the gains of privatization to be realized. This, in essence, means the conditions of a perfect market. ${ }^{23}$ In this sense, good regulation requires the creation and sustenance of competition in the economy. This is rather ironic because the impulse to privatize derives from the impulse to deregulate. Governments that want to privatize begin by deregulating the economy by relaxing their dominance in economic activities and opening space for private firms to compete with government-owned enterprises.

In another perspective, regulation is a means to protect the human rights of citizens from the juggernaut of the market economy. Here the regulator controls both the production and pricing of goods and services to make them available and affordable to a broad category of citizens and there are no other social or environmental costs of producing and consuming such goods. ${ }^{24}$ This objective is well captured in a World Bank publication thus: “... experience shows that privatization often leads to increased tariffs unaffordable to poor households and sometimes to outright exclusion of poor rural areas viewed as unprofitable by private providers. Only pro-poor regulation, including subsidies for the poor, can neutralize these drawbacks of private service delivery". ${ }^{25}$ The regulator, therefore, carries a burden to make sure that newly privatized enterprises protect the rights of the people, especially the employment rights of labour and the welfare of their consumers and client.

The Nigerian regulatory condition was not improved before privatization begun in earnest. By the time Babangida began the privatization programme as part of the IMF-imposed Structural Adjustment Programme (SAP), Nigeria could not boast of strong regulatory commissions and even the most rudimentary regulatory regime for utility markets. There was no statute on competition even till date. ${ }^{26}$ This is typical as Joseph Stiglitz suggests that privatization

23 ibid 2-5

24 Bernardo Bortolotti and Domenico Siniscalco, The Challenges of Privatization: An International Analysis (OUP 2004) 110-111.

25 Tatyana P. Soubbotina, Beyond Economic Growth: An Introduction to Sustainable Development (The World Bank 2004), 80.

26 The Nigerian National Assembly just passed a competition law in early this year. The Act has not been signed by the President and, therefore, is yet to become law. Editorial, "Senate Passes Federal Competition and Consumer Protection Bill" Leadership (8 June 2017) < http://leadership.ng/2017/06/08/ $\%$ E2\%80\%8Esenate-passes-federal-competition-consumer-protection-bill/> accessed 31 August 2017. 
often occurred before institutions of efficiency and fair control had developed. ${ }^{27}$ The standard advice from privatization advocates, based on the tragic experiences in Russia and other transition economies, is that privatization should begin only after a strong regulatory regime has been put in place. ${ }^{28}$ This is to avoid the kind of criminal assetstripping and crony capitalism that resulted in the former Soviet republics.

There are two broad approaches to creating a regulatory regime. The government may establish an omnibus regulator who takes charge of privatized enterprises and regulates their performance or establish industry-based agencies to regulate their respective industries. Nigeria took the second option. Regulatory agencies were established to deal with different industries. Some of these agencies were in existence before some of the enterprises were privatized. For example, before Nigeria liberalized the telecommunications sector and licensed private telecom companies who carry GSM networks nationwide, the National Communication Commission (NCC) had existed as a regulator. Also, the Nigerian Electricity Regulatory Commission (NERC) was established in 2006, whereas the electricity industry was only privatized in 2013. But these agencies could not establish the required regulatory regimes before completing privatization. This was so evident in the case of NERC, where many of the prescribed market structures that should have preceded privatization, especially the development of a contractbased trading, had not been established before assets were handed over to the core investors. ${ }^{29}$

The problem with the Nigerian privatization exercise is the lack of capacity of regulatory agencies to control the pricing and delivery of services by the new private enterprises. This is very manifest in the telecommunications sector where privatization has recorded its greatest apparent success. Nigeria has licensed major GSM network companies, including the MTN, V-MOBILE and GLOBACOM. By, industry estimation, Nigeria is one of the fastest growing mobile phone users in the world. The MTN records highest revenue in Nigeria than elsewhere, including

27 Joseph Stiglitz, "What is the Role of the State?" in Macartan Humphreys, Jeffrey D. Sachs \& Joseph Stiglitz (eds.,) Escaping the Resource Curse (Columbia University Press 2007) 39.

28 Karla Hoff and Joseph E. Stiglitz, "Modern Economic Theory and Development" in Gerald Meier and Joseph Stiglitz (eds.) Frontiers of Development Economics: The Future in Perspectives (OUP 2001) 419.

29 Electric Power Sector Reform Act 2006, s. 25. 
South Africa, its headquarters and country of incorporation. MTN rakes in one-third of its revenue from Nigeria alone. ${ }^{30}$ For example, MTN in the first quarter of 2017 recorded over 17 per cent increase in total revenue in spite of 2.3 per cent decline in customer subscription. ${ }^{31}$ In spite of growing revenue to telecom companies, Nigeria records one of the most expensive calls in the world. Before the advent of Glo Mobile, per minute billing (PMB) was $\$ 50$. The networks refused to introduce per second billing (PSB) until Globacom launched its Glo Mobile on per second billing. Even the regulator, NCC could not force the network operators to migrate to per second billing till Glo through its marketbased strategies ushered per second billing which is more equitable than per minute billing. ${ }^{32}$

It is not only high cost that is the problem with telecommunication in Nigeria. The quality of services remains very poor. The rate of dropped calls is very high. Many of the networks cannot sustain unbroken service for a week. This has translated to a high cost of doing business for both small and medium enterprises and big corporations in Nigeria. An industry-wide study by an independent consultant reports massive and pervasive bad services from all the networks. Some of the identified poor services include the difficulty of connecting from one network to another; the regularity of uncompleted calls, rapidity of dropping calls by all the networks. The report states that about 48.8 per cent of respondents experience loss of service sometimes and more than 50 per cent report drop calls from the networks. ${ }^{33}$

Why is the cost of a mobile phone call so expensive in Nigeria? Some of the telecom operators explain that the problems are the lack of infrastructural backbone for telecommunication in the country and the high cost of doing business, including huge licensing fees. Although

30 Staff Writer 2, "MTN Settles Nigeria Fine \& Looks at Listing at the Nigeria Stock Exchange" African Business Central (11 June 2016) < http://www.african businesscentral.com/2016/06/11/mtn-settles-nigeria-fine-looks-at-listing-onthe-nigerian-stock-exchange/> accessed 31 August 2017.

31 Mayowa Tijani, "MTN Nigeria Revenue Jumps by 11.6\% Despite Drop in Customers." The Cable (3 May 2017) < https://www.thecable.ng/mtn-nigeriarevenue-jumps-11-6-despite-drop-customers > accessed 31 August 2017.

32 Mobolaji E. Aluko, "The Arithmetic of PMB, PSB and Interconnectivity: Telecommunication Charges in Nigeria" (16 November 2003) < http:// www.jidaw.com/itsolutions/telecomm3.html> accessed 1 September 2017.

33 Nigerian Communication Commission, Nigeria Consumer Satisfaction Survey Final Report (Final Report Part 2: Data Analysis, November 2012) 39-40. 
the government liberalized the telecommunications sector by dismantling the monopoly of the Nigerian Telecommunications Company (NITEL) over the sector, it failed to increase infrastructural development in the sector before the sale of frequencies to private companies. Many years of inefficient monopoly and corrupt military dictatorship had destroyed telecommunications infrastructure and undermined development in the sector. What is required, and what government failed to do was to invest more in developing a strong backbone for telecommunication before privatization. The sunk costs required in the sector are so huge that private investment may not be forthcoming, or if it does, it will come with a great price for telecom services. The counter-argument will be that the distress in the sector was so overwhelming that quick and complete liberalization of the sector were urgent and pressing. Private ownership will redound to greater efficiency and more infrastructural development over time. So, as the standard argument in the privatization debate goes, it is better to privatize today and hope that efficiency gains arising from better management practices will induce policy changes in the sector. This is the so-called "shock therapy".

The absence of infrastructure and good policy environment in the electricity and telecommunications sector is partly caused by government's focus on revenue generation during privatization to the detriment of productive and distributive efficiency. ${ }^{34}$ It seemed that the liberalization of the telecom sector was necessitated more by fiscal consideration rather than efficiency concern. The government overcharged the operators for license and failed to invest the funds in capacity building. The government should not have overtaxed telecom operators. Overtaxing the operators reduces their financial capacity to provide better services. In addition, lack of capacity in ancillary sectors like the energy sector further weakened the capacity of the network operators to maintain decent service for a long period of time. ${ }^{35}$

These problems do not suggest that it was wrong to liberalize the telecom sector and privatize the electricity sector or that government

34 This is more so in the electricity sector where the design of the auction or bidding process emphasized more of revenue earning rather than overall economic efficiency. See Bernardo Bortolotti et al (n 24) 16-20 on the choice of privatization method.

35 ACTON, "Why Nigerians Get Poor Telecoms Quality Service" < http:// technologytimes.ng/atcon-poor-telecoms-service-quality-nigeria/> accessed 6 September 2017. 
ought to have maintained the monopoly of Nigeria Telecommunications Limited (NITEL) and the National Electric Power Authority (NEPA). To a large extent, the government proceeded with caution in the telecom sector. It did not immediately privatize NITEL. It began with commercialization and management contract. But, it turned out that both commercialization and management contract failed to turn-around the affairs of NITEL. Later, there were multiple failed attempts to sell NITEL and MTEL. Later in 2014, BPE managed to sell NITEL to a private firm. The privatization of the successor companies of the Power Holding Company of Nigeria (PHCN) was more orderly and successful. ${ }^{36}$ Building up regulatory capacity is important for a successful privatization. From the perspective of poverty alleviation and access to basic service by the poor, the most important issue after privatization is the price of the services post-privatization. In the Nigerian case, before liberalization, access to telephone services - whether in terms of mobile phones or landlines - is non-existent. So, comparatively, in spite of the high cost of telephone services in Nigeria, the rationale for liberalizing the sector is still strong, in spite of very poor service quality.

Another problem associated with regulating the telecom sector is the extent of the power of the regulator over business practices. Very early in the day, a big crisis developed between the NCC and the GSM operators over the right of the former to issue new enforcement rules. The telecom sector is under heavy tension arising from the dispute between the Association of Licensed Telecommunication Operators (ALTON) and the National Communication Commission (NCC) over the power of the latter to regulate the sector in particular manners the former deems either unconstitutional or inefficient. The NCC defends its regulations on the ground of legislative mandate and the protection of public interest and the telecommunication policy of the Obasanjo government. In this altercation, there is so much hot air, but little clear thinking. The combatants clash like armies by night.

The combatants largely overlook the intricacies arising from the intersection of law and economics. In fact, telecommunication is one of the business enterprises that task the scholarly resources of law and economics most. Regrettably, this disciplinary approach to the study

36 By virtue of Section 1 of the Electric Power Sector Reform Act, 2005, the National Electric Power Authority (NEPA) was transformed into a Power Holding Company of Nigeria (PHCN) and further broken into 18 different companies, which are collectively referred to as successor PHCN companies. 
of law is not developed in Nigeria. As Nigeria integrates into the main swell of the global economy and continues to engage in market reforms, the law faculties must begin to train students who exercise proficiency in issues of economic development, the rule of law and public policy. This requires the overhauling of law school curriculum to give place to "perspective courses", that is, courses that merge together insights from different areas of study to analyse a thematic discourse. In the interim, the law journals and newspaper law papers should devote more space to issues of economic reform and the rule of law.

\section{UNDERSTANDING THE RULE OF LAW APPROACH TO POLICY AND REGULATION}

The rule of law approach to regulation of any sector (whether telecom or electricity) is not just a matter of understanding how the regulatory law says the sector should be regulated. We must at least supplement and interpret the provisions of the regulatory law with the provisions of the constitution and principles of constitutional law. Let us illustrate this with Section 70 of the NCC Act 2003. This section empowers the NCC to issue rules and directives for telecom business in Nigeria. The NCC has construed from this provision the power to make some stringent enforcement regulations, which the operators find financially onerous, legally burdensome and constitutionally suspicious. The rule of law approach asks what the regulator, NCC in this case, can validly do. How can it regulate business relationship between the operators and the social relationship between the operator and the community? The template for sketching the market and social responsibilities of telecom operators in Nigeria requires knowledge of the fundamentals of the rule of law as sanctioned by the constitution and applied in the context of best business practices. We will examine hereunder some of these fundamentals as they apply to the key features of the regulatory environment.

\subsection{The Rule of Law and Competition Policy}

One of the basic policies defining the reform of telecom and electricity markets in Nigeria and their effective regulation is the creation of a competitive market for telecom services and products. ${ }^{37}$ Although

37 National Communication Commission Act, s...; Electric Sector Reform Act 2005, s. 32 . 
Nigeria is yet to have an operative competition law, ${ }^{38}$ there is a competition policy as can be deduced from the many economic reform programmes starting from the National Economic Empowerment and Development Strategy (NEEDS) ${ }^{39}$ up to the current Economic Reform and Growth Programme (ERGP). ${ }^{40}$ NEEDS wants the government to stay away from key roles in businesses and intervene only when it needs to correct failures in the free market (the founding document does not use the exact words). It articulates an economy that is privatesector-driven and geared towards both allocative and dynamic efficiency. ERGP also marshalled strategies that would make "the Nigerian business environment more competitive". ${ }^{41}$

In the discourse of economic regulation, a competition policy operates as a deregulation policy. Standard liberal economic theory prescribes that efficiency is achieved when private actors voluntarily enter into economic transactions in response to price signals. As the US Supreme Court puts it, "competitive forces will yield the best allocation of our economic resources, the lowest prices, the highest quality and the greatest material progress, while at the same time preserving an environment conducive to the preservation of our democratic political and social institution". ${ }^{42}$

A competition policy tries to establish the ideal-typical perfect market when the cost of entry and exit is lowered and distortion is reduced to the minimum. Because competition policy is inherently deregulatory, competition law often focuses on de-emphasizing regulatory behaviours that impose unnecessary transaction costs on

38 In July 2017 the National Assembly passed a competition law (Federal Competition and Consumer Protection Commission Bill) after the failure of many previous drafts to pass. The bill provides for the Federal Competition and Consumer Protection Commission (FCCPC) to replace the Consumer Protection Council (CPC) but to date the bill has not been signed into law. So, there is still no comprehensive competition regulation in Nigeria. See Aanuoluwa Omotosho and Tobi Opusunju, "Nigeria Sees Competition czar as Senate Passes Competition and Consumer Protection Bill"Tedge News(9 June 2017)<https:// itedgenews.ng/2017/06/09/nigeria-competition-czar-senate-passesconsumer-protection-bill/> accessed 6 September 2017.

39 Nigerian National Planning Commission, Meeting Everyone's Needs: National Economic Empowerment and Development Strategy (2004) Chapter 5.

40 Ministry of Budget and National Planning, Economic Recovery and Growth Plan 2017-2020 (February 2017) Chapter 4.

41 bid 81.

42 Northern Pacific Railway Co. v. The United States, 356 US 1 (1958),4. 
business enterprises and discourage efficient allocation of resources by market forces. To achieve the purposes of deregulating the economy and allowing for free competition, the authorities must use competition policy to encourage self-regulation after setting proper standards. The essence of the free market economy is that economic behaviour follows price signals, which reflect productive efficiency. Therefore, a prudent regulator is advised, as much as possible, and in line with the competition policy, to remove any regulatorydistortion of economic activities. To this end, the focus should be to allow as much selfregulation as possible as long as firms do not capture market power unfairly and in a manner that frustrates the engendering of competitive business environment that encourages more productive cost economizing and increases consumer welfare. ${ }^{43}$

Obviously, the NCC, as a regulator, understands the overriding importance of ensuring the realization of the deregulatory intent of the competition policy of the Federal Government. But, the challenge is how to execute this policy in the context of other responsibilities outlined in the NCC Act and the constitution. As a regulator, NCC has a public duty to ensure fair competition and protect customer welfare. Section 4 of the Act outlines the following functions:

i. Regulating for fair and effective competition;

ii. Regulating to deal with market failures specific to telecommunication sector;

iii. Regulating to deal with social inequities and other distributional problems of social justice; and

iv. Regulating for greater micro-economic and social benefits in the acquisition and use of telecommunication technology for public benefits. ${ }^{44}$

These functions show that the act intends sectoral regulation in addition to the deregulation of the economy pursuant to a competition policy. The NCC will not be an effective regulator of the quality of service and customer welfare if it does not properly mainstream its regulatory work within the economy-wide deregulatory competition policy. One of the problems faced by developing countries or countries transiting to a full market economy is the difficulty of establishing the

43 See generally for discussion on this perspectives, Sam Amadi, Privatization \& Public Good: The Rule of Law Challenge (CPPR 2009) chapter 3.

44 National Communication Commission Act 2003, s. 4. 
boundaries between deregulation and regulation, or better still, how to regulate in a deregulating economy.

Some scholars in law and economics are of the view that once a country subscribes to a competition policy, it should enact a comprehensive and generic competition law and sectoral regulation should be eliminated or reduced to the barest minimum. This is the view of the International Telecommunication Union (ITU). It argues, "the trend today is towards deregulation. Some traditional forms of telecommunication regulations are now viewed as having been more damaging than beneficial to the development of the national telecommunication infrastructure and services ... regulation of interconnection represents one of the small number[s] of exceptions to the general rule. In most cases, regulation can and should be minimized". ${ }^{45}$ The World Bank handbook of telecommunication regulation seems to support this view. ${ }^{46}$ But the study of international best practices suggests that what adduces to abetter result is a creative and intelligent mixture of competition law and well-targeted sectoral regulation. ${ }^{47}$

The World Bank and ITU handbooks advocate for light-handed regulation, something akin to deregulation. ${ }^{48}$ The debate in mainstream law and economic discourse about the blending of generic competition law and sectoral regulation pays no attention to issues of public law, particularly constitutional law and the sub-genre of human rights law. From a rule of law approach, what does the Nigerian Constitution say about the extent of deregulation in key sectors of the national economy? Do the fundamental objectives and directive principles of state policy in the Constitution allow for the sort of deregulation and self-regulation that the operators demand, or do they impose on the government a responsibility of more intrusive and extensive regulation? ${ }^{49}$

45 Hark Intven \& McCarthy Tetrault (eds.), Telecommunication Regulation Handbook (Module 1: Overview of Telecommunication Regulation <https://www.itu.int/ ITUD/treg/Documentation/Infodev_handbook/1_overview.pdf $>$ accessed 7 September 2017.

46 Colin Blackman \& Lara Srivastava, Telecommunications Regulation Handbook (Ten Anniversary Edition) (the World Bank \& ITU 2001) 30-33.

47 World Bank, Economic Growth in the 1990s: Learning from a Decade of Reform (World Bank Publications 2005)19-22.

48 ibid 30-32.

49 The Fundamental Objectives and Directive Principles of State Policy are contained in Chapter 2 of the Constitution of the Federal Republic of Nigeria, 1999. 
Section 16 of the Constitution sets out the economic objectives that should guide regulation, deregulation and reregulation as follows:

(1) The state shall, within the context of the ideals and objectives for which provisions are made in this constitution; (a) harness the resources of the nation and promote national prosperity and an efficient, a dynamic and self-reliant economy; (b) control the national economy in such manner as to secure the maximum welfare, freedom and happiness of every citizen on the basis of social justice and equality of status and opportunity (c) without prejudice to its right to operate or participate in areas of the economy, other than the major sectors of the economy, manage and operate the major sectors of the economy; ... ${ }^{50}$

From these provisions, there is clear constitutional authorization for regulation of the telecom sector to achieve both efficiency and social justice. The constitution requires an economy that is efficient but also secures "the maximum welfare, freedom and happiness of every citizen on the basis of social justice and equality of status and opportunity". What is the legal status of this directive principle? The courts have held that these directive principles are not justiciable at the instant of a person who alleges that his rights have been infringed by the acts of government or another citizen. ${ }^{51}$ But, this does not mean that they are divested of legal effect. These directives sought to guide executive actions in Nigeria. Every branch of government ought to reflect these directives in their policies and programmes, and where they fail to incorporate them, or act contrary to their requirement, such actions can be held as unconstitutional.

This is particularly so when another provision of the constitution obligates a body or agency to follow any of the directives in its work, for example, the Federal Character Commission that ought to ensure

50 Constitution of the Federal Republic of Nigeria 1999, s. 16.

51 Olafisoye v. Federal Republic of Nigeria (2004) 4 NWLR (Pt. 894) 581. The courts rely on the provisions of Section 6 of the Constitution to hold that failure to enforce any of the so-called "economic, social and cultural rights under Chapter 2 of the constitution cannot be adjudicated in court. The section states that "The judicial Power... shall not except as otherwise provided in the Constitution, extend to any issue or question as to whether any act or omission by any authority or person or as to whether any law or judicial decision is in conformity with the Fundamental Objectives and Directive Principles of State Policy set out in Chapter 11 of the Constitution". 
equity in public service of the federation. The Supreme Court has held that although the fundamental objectives are themselves not enforceable in court, where a law has enacted those obligations or principles, they become enforceable in court against public officers and institutions. ${ }^{52}$

Both the NCC and the NERC, as administrative agencies, belong to the fourth branch of government. As US Supreme Court Justice Robert H. Jackson stated in the classical case, FTC v. Ruberiod Co: ${ }^{53}$

The rise of administrative bodies probably has been the most significant legal trend of the last century and perhaps more values today are affected by their decisions than by those of all of the court, review of administrative decisions apart. They also have begun to have important consequences on personal rights.... They have become a veritable fourth branch of government, which has deranged our three branch legal theories as much as the concept of a fourth dimension unsettles our three-dimension thinking.

As members of the fourth branch of government, these agencies should be guided by constitutional obligations. Since the constitution prescribes efficiency and social welfare as the directive principles of management of economic resources in Nigeria, these regulatory agencies have an obligation to blend competition policy and sectoral regulation in the exercise of their mandate. In this wise, I consider hereunder some of the criteria that ensure compliance with the constitution and promotion of economic efficiency and a competitive market in telecommunication. These criteria are legal as well as economic.

\section{SEPARATION OF POWER AND REGULATORY ACCOUNTABILITY}

Regulatory agencies, as members of the executive branch, are required to observe the principles of separation of power. How do we conceive separation in the regulatory regime? Separation of power is an accountability framework in the exercise of regulatory powers. ${ }^{54}$ As

521 AG Ondo $v$ AG Federation (2002) 9 NWLR (Pt. 772) 22.

53343 U.S. 470 (U.S Sup, Ct. 1952).

54 This accountability framework in the context of separation of power is fairly undermined in the administrative state where the legislature has transferred its rulemaking powers to regulatory agencies within the executive branch. See 
Cass Sunstein wisely observes, when regulation fails, it might be the failure of constitutional goals. It could be because of the "absence of political deliberation or accountability". ${ }^{55}$ In a nutshell, separation of power requires that different branches of government do not encroach on the functions allocated exclusively to the others. In the rendition of legal philosophy, separation of power recognizes that political freedom is protected if the body or person who makes the law differs from the bodies that interpret and execute the law.

It is easy to determine that the principle of separation of power has been violated when the executive performs a legislative function or vice versa. But, it is not so easy when the violation is insidious and discreet. Separation of power violation occurs as well when an executive agency issues regulations and rules, which expand its powers beyond what the legislature has authorized in the enabling act. The law clearly requires that a subsidiary legislative or administrative direction based on an enabling act does not exceed the parameters of the act. A regulatory action that crosses such boundary would violate regulatory accountability. ${ }^{56}$

Political accountability in the context of separation of power would require that the regulatory agency fulfil its mandate denoted by an Act of National Assembly. It cannot pursue economic orthodoxy to the extent that it forgoes the constitutional requirement of blending deregulation and sectoral regulation or forego clear mandate in the Act. The doctrine of "regulatory forbearance", as proposed by economists, may be prudential but could amount to non-compliance with the constitutional and legislative mandate.

It will also be a violation of the principle of separation of power for NCC to interpret its power under the Act to require issuing directives and regulations that go beyond the contemplation of the NCC Act. This raises the issue about the degree of deference an administrative agency should enjoy from judicial review. The NCC is the custodian of the expertise required for the effective regulation of the sector. Therefore, it rightly argues for powers to effectuate its legislative mandate. But

David M. O’Brien, Constitutional Law and Politics: Struggles for Power and Governmental Accountability (Volume One) (W.W. Norton 20000) 367-368.

55 Cass Sunstein (n 22) 74.

56 Both the Nigerian and US Supreme Court have invoked their judicial review power to reinforce regulatory accountability. See Director of S.S.S. v Agbakoba (1999) 3 NWLR (Pt.593)314 and Abbot Laboratories v. Gardiner 387 U.S. 136, 140-141 (1967). 
the execution of its legislative mandate may violate rights guaranteed by the constitution. Therefore, it is not enough to plead good faith and expertise. The court should not defer to the agency's interpretation and application of its powers if such derogate from its legislative mandate and undermines judicial functions. ${ }^{57}$

\section{PROTECTION OF FUNDAMENTAL HUMAN RIGHTS}

Judicial review of the exercise of regulatory powers will also extend to a determination whether agency's interpretation or execution of powers infringes guaranteed rights? This is where the protection of fundamental rights becomes important. Sadly, many market reform advocates do not consider the importance of protecting these rights. The result is that the regulator is often thrown into avoidable legal crisis. The most important rights in these instances are the rights to a fair hearing and personal property. The case law on the right to fair hearing is well developed in Nigeria as well as in other jurisdictions. The Supreme Court in Stitch v. A.G. Federation laid a clear rule that even executive or independent agencies created by Acts of Parliament, whenever they are to make determinations that affect the rights of private or corporate citizens, must comply strictly with fundamental rights, especially the right to fair hearing under section 36 of the constitution. ${ }^{58}$

Important aspects of regulatory actions include rulemaking and enforcement of sanctions for breach of rules. What duties do the right to fair hearing impose on such regulators like the NCC and the NERC when undertaking such regulatory actions? Primarily, it imposes the duty of complying with procedural and substantive due process. The power to seal off and detain equipment and facilities, to revoke licenses, to request for basic information in respect of national interest, and impose several administrative fines may pose troubles for the agency because of possible violations of the fair hearing principle. The Supreme Court in a long line of cases including (LPDC $v$ Fawehinmi, ${ }^{59}$ Oyelade $v$. Araoye, ${ }^{60}$ Alakija v. Medical Disciplinary Committee $)^{61}$ has held that any

57 The US Supreme Court articulated this position in the classical case of Chevron USA.

585 NWLR (Pt. 47) 1007.

59 (1985) 3 NWLR (Pt. 7) 300.

60 (1968) NMLR 46.

61 (1959) 4 FSC. 38. 
determination that engages the public agency in acting judicial must follow the full complement of a fair hearing.

The policy dilemma for the regulator is how to understand the extent of the duty to act judicially, that is, to hear the other party and not to be a judge in one's case. How could the agency make rules, investigate alleged infractions and impose fines in a manner that it will not be guilty of violating fair hearing? Therefore, if the agency, after a proper investigation, determines that the operator has violated the code and imposes fines, it risks judicial nullification except it properly shields itself from being a judge in its own case. This was the issue in the Fawehinmi case where the Attorney-General who raised a complaint of unprofessional conduct against Fawehinmi supervised the process that disciplined him for unprofessional conduct. The Supreme Court nullified the proceedings for want of due process. ${ }^{62}$ This poses the challenge of walking the tight-rope to achieve agency mandate without undermining the duty to act judicially.

To act judicially and effectively achieve regulatory mandate in the present market orthodoxy is a complex problem that will require a comprehensive review of the principles and practices of administrative law in Nigeria. This requires the enactment of composite administrative law procedures like the US Administrative Procedure Act (APA). ${ }^{63}$ This law will set out all the reviews standards for different kinds of agency work. It will also set out a procedure for rule-making by the administrative body. Therefore, when the agency intends to make a directive or ruling of a technical nature, it will advertise to relevant stakeholders, especially members of the epistemic community and the business operators, and offer theman opportunity to challenge the agency's episteme and offer a different standard to regulate that aspect of the industry. This composite law will also differentiate the kind of rulings and directions that require full hearing from those that do not. In the absence of such an administrative code support for regulatory mindfulness, the regulatory landscape will remain incoherent.

\section{CONCLUSION}

The purpose of privatization of key sectors like telecom and electricity has been to ensure abetter quality of services through private sector

62 (1985) 3 NWLR (Pt. 7) 300.

63 Administrative Procedure Act 5 USC 1946. 
efficient allocation and utilization of resources. The assumption that the private sector would be more efficient than the public sector is something of a standard doctrine of the liberal economic orthodoxy. It is predicated on fundamental theorems of welfare economics, which rests on falsifiable assumptions that (1) the market is perfectly competitive; and (2) that there are no other costs (social and environmental) that are integrated into the equilibrium prices. To achieve the strategic objective of privatization, at least in the transitional stage, government must regulate the activities of private firms in the privatized industry.

Markets are never perfectively competitive and oftentimes produce negative externalities either in the form of pollution or nuisance or in the form of excluding people from access to basic services, thus making regulation becomes inevitable. ${ }^{64}$ In the utility market, such exclusion could be in the form of higher cost or insufficient coverage. But the debate is not whether there should be regulation of private sector managed infrastructure but how. The dominant neoliberal economics has influenced the conception of regulation as merely dealing with transaction costs in a manner that enhances the functioning of the market, rather than in a manner that achieves other non-market goals. As always, the when and how of privatization would depend on the values and goals that one considers important.

The Nigerian Constitution has proclaimed such strategic values and goals in the Fundamental Objectives and Directive Principles of State Policy in chapter 2 and the Fundamental Human Rights in Chapter 4. This imposes a rule of law approach to regulation. Such an approach will not only cure market failure but go further to promote civil and political rights as well as social and economic rights of Nigerian citizens and residents.

64 See Jose A. Gomez-Ibanez, Regulating Infrastructure: Monopoly, Contracts and Discretion (Harvard University Press, 2003) 18-22 for a market-based justification of regulation in private infrastructure markets. 